carrier complex (M.D. Scharff, Albert Einstein College of Medicine). Both the clustered substitutions in the hypervariable regions, and the occasional ones in the framework can therefore be accounted for by selection for antigen binding.

It would be a mistake however to assume that all mutations in expressed immunoglobulin genes must have been specifically selected: indeed, some are silent and could never have been subjected to selection. These are presumably the "neutral mutations" of the immune system. But if the pattern of mutations requires no special explanation, it is possible that the rate of mutation may. Certainly many immunologists are wondering about possible mutagenic reactions associated with the class switch. Notwithstanding the considerable difficulties associated with the elucidation of molecular mechanisms of immunoglobulin gene rearrangement,

. see Robertson, M. Nature 287, 390 (1980).

2. Brack, C., Hirama, M., Lenhard-Schuller, R. \& Tonegawa, S. Cell 15, 1 (1978)

3. Kurosawa, Y., von Boehm, H., Haas, W., Sahano, H., Traunecker, R. \& Tonegawa, S. Nature 290, 565 (1981).

4. Early, P, et al. Cell 19, 981 (1980).

5. Sakano, H. et al. Nature 286, 676 (1980).

6. Burrows, P., Lejeune, M. \& Kearney, J.F. Nature 280, 838 (1979).

7. Riley, S.C., Brock, E.J. \& Kuehl, W.MI. Nature 289, 804 (1981).

8. Gearhart, P., Johnson, N.D., Douglas, R. \& Hood, L. Nature in the press.

. Bothwell, A.L.M. et al. Cell in the press. the issue of mutation rate may be resolved more quickly by research at this level than by arguments about sequences, because arguments about the mutation and selection of sequences depend on a detailed understanding of the relationship between the sequence of an immunoglobulin and its antigenbinding properties and this is usually unknown.

However, each antibody molecule can now be seen as the end product of a series of selective steps, beginning with the germline genes. The germ-line V, J and D genes have presumably been selected in the course of evolution for their ability to produce proteins that will bind to common environmental antigens. There follow at least two rounds of somatic selection by antigen. The first acts on the V-J and V-D-J recombinations that produce $\operatorname{IgM}$. It is followed by at least one more round of somatic selection favouring mutations that produce efficient binding to the same antigen, or indeed to any other antigen present in large enough quantities to encounter the mutant cell. A detailed analysis of hybridoma proteins from immunized and hyperimmunized mice, such as Bothwell and his colleagues have already begun, may help to show how far antigenic selection could account for the range of antibodies a single mouse is able to produce against a single antigen.

\section{The expanding Earth}

from A.D. Stewart

TWENTY-FIVE years ago the University of Tasmania hosted a conference on continental drift organized by Professor S.W. Carey, at which he presented his now famous review documenting the detailed geological evidence for continental breakup and separation during the Mesozoic and Cenozoic, with explanations for major Earth structures like oroclines (hair-pin bends in mountain belts) and sphenochasms (wedge-shaped oceanic areas like the Bay of Biscay) thrown in for good measure. Most of Carey's views on inter- and intracontinental motions are now, of course, generally accepted but the basic mechanism he postulated - Earth expansion sufficient to have generated all ocean basins since the Palaeozoic engenders in most geologists the same feelings of incredulity that continental drift did 25 years ago.

February 1981 saw the sequel to the Tasmanian meeting - the Expanding Earth Symposium at the University of Sydney, again organized by Carey - at which two new lines of evidence supporting major Earth expansion were discussed. The first was the work of Andy Glikson

A.D. Stewart is in the Department of Geology at Reading University.
(Geology 7; 449, 1979) which highlights the lack of geochemical evidence for oceanic crust, or indeed any mantle-derived crust, surviving from the Proterozoic, and the palaeomagnetic and stratigraphical evidence for continental integrity over this period. This was backed up by Keith Crook's analysis of the global abundance of ophiolites and turbidites, both generally accepted indicators of oceanic crust. Their abundance decreases exponentially with increasing age back to the end of the Proterozoic $\left(\sim 10^{9}\right.$ years ago) when they disappear completely from the geological record. This is not just a sampling effect because turbidite sediments are well known from the Archaean $\left(>2.5 \times 10^{9} \mathrm{yr}\right)$. Crook's interpretation of these data is similar to Glikson's - there were no ocean basins in the Proterozoic because the Earth had only about 60 per cent of its present radius.

The second new line of evidence favouring expansion comes from palaeomagnetism. Embleton and co-workers ( $J$. Geophys. 49; 20, 1981) showed that for quite long periods during the Proterozoic, continental blocks such as North America and Australia in their present relative positions had common polar wandering paths. They interpret this surprising result, coupled with the missing oceanic crust, as arising from Earth expansion during the late Proterozoic. Pure Earth expansion has the effect of leaving continental centres in the same coordinate position and so has no effect on the polar wandering paths. The problem is to see how the relative continental motions during the Phanerozoic, which palaeomagnetism brings out so clearly, could have returned the continents to the relative positions they had in the Proterozoic.

The main counter-arguments to expansion were the well known length of day calculation (Runcorn Nature 204; 823, 1964) based on daily and annual growth increments in corals, the lack of secular change in global sea level over the Phanerozoic (Vail et al. Mem. Am. Ass. petrol. Geol. 26; 83, 1977) coupled with near stability in the volume of the hydrosphere (Anderson Rev. Geophys. Space Phys. 13; 37, 1975), and my demonstration that for the past 5 years, half or more of the subduction required by plate tectonics on an Earth of fixed radius is actually occurring. These arguments give a maximum rate of change in Earth radius of $0.1 \mathrm{~cm} \mathrm{yr}^{-1}$ since the Devonian, in gross conflict with the idea of accelerating expansion during the late Phanerozoic. This conclusion is backed up by the provinciality of Palaeozoic faunas, pointed out by Clive Burrett, which suggests that major ocean basins existed at that time.

All this, however, fails to provide any hard evidence about palaeoradius in the Proterozoic, to which attention is now focused. Only Stewart's (J. geol. Soc. Lond. 133; 281, 1977) palaeogravity method, which compares computed geotherms with mineralogical evidence for the actual $P-T$ conditions in the crust and upper mantle, gives any help here. Palaeoradius can easily be calculated from the surface gravity field provided that Earth mass and the universal constant of gravitation are known. Gravity seems to have remained within a factor of two of its present value throughout Earth history, implying a rate of change in radius $<0.1 \mathrm{~cm}$ $\mathrm{yr}^{-1}$ and hence limiting late Proterozoic expansion to $<1,000 \mathrm{~km}$. This is too small by a factor of 2.5 to solve the problem of the missing oceanic crust.

It is to be hoped that the basically sound palaeomagnetic technique for measuring palaeoradius will soon be applied to early Proterozoic basic dykes across a stable continent such as Canada. Using samples collected specifically for the purpose, it should be possible to reach a definite decision about the likelihood of late Proterozoic Earth expansion. Published palaeoradius estimates using the palaeomagnetic technique have always used samples from Phanerozoic rocks and even these, it was pointed out at the meeting, did not always come from stable continental areas as required by theory, so that the validity of the palaeoradii was open to doubt. 